University of Nebraska - Lincoln

DigitalCommons@University of Nebraska - Lincoln

Transactions of the Nebraska Academy of

Sciences and Affiliated Societies

Nebraska Academy of Sciences

3-2-2021

\title{
Phenology of Antler Casting and Occurrence of Late-Breeding in Nebraska White-Tailed Deer
}

\author{
Brian C. Peterson \\ University of Nebraska at Kearney, petersonbc@unk.edu \\ Patrick D. Farrell \\ Headwaters Corporation, Kearney, NE, farrellp@headwaterscorp.com \\ Dave Fehlhafer \\ Ecological Solutions, Doniphan, NE, davefehlhafer@gmail.com \\ Miranda C. Reinson \\ University of Nebraska at Kearney, reinsonmc@lopers.unk.edu \\ Dustin H. Ranglack \\ University of Nebraska at Kearney, ranglackdh@unk.edu
}

Follow this and additional works at: https://digitalcommons.unl.edu/tnas

Part of the Animal Studies Commons, Biology Commons, Other Animal Sciences Commons, and the Zoology Commons

Peterson, Brian C.; Farrell, Patrick D.; Fehlhafer, Dave; Reinson, Miranda C.; and Ranglack, Dustin H., "Phenology of Antler Casting and Occurrence of Late-Breeding in Nebraska White-Tailed Deer" (2021).

Transactions of the Nebraska Academy of Sciences and Affiliated Societies. 529.

https://digitalcommons.unl.edu/tnas/529

This Article is brought to you for free and open access by the Nebraska Academy of Sciences at DigitalCommons@University of Nebraska - Lincoln. It has been accepted for inclusion in Transactions of the Nebraska Academy of Sciences and Affiliated Societies by an authorized administrator of DigitalCommons@University of Nebraska - Lincoln. 


\title{
Phenology of Antler Casting and Occurance of Late-Breeding in Nebraska White-Tailed Deer
}

\author{
Brian C. Peterson, ${ }^{1 *}$ Patrick D. Farrell, ${ }^{2}$ Dave Fehlhafer, ${ }^{3}$ Miranda C. Reinson, ${ }^{1}$ and Dustin H. Ranglack ${ }^{1}$ \\ 1 Department of Biology, University of Nebraska at Kearney, 2401 11th Avenue, Kearney, Nebraska 68849 \\ 2 Headwaters Corporation, 4111 4th Avenue, Suite 6, Kearney, Nebraska 68845 \\ 3 Ecological Solutions, 203 W Bartelt Avenue, Doniphan, Nebraska 68832
}

*Corresponding author: petersonbc@unk.edu, (308) 865-1589

\begin{abstract}
White-tailed deer (Odocoileus virginianus) in Nebraska primarily breed in November (stimulated by photoperiod), but this season extends into December and January for unfertilized females and healthy fawns reaching the appropriate breeding weight by winter. Variation in the typical mating period can be attributed to geographic region, skewed sex ratios, and fawns reaching sexual maturity during their first year of birth. During April of 2019, we observed late season breeding by a male white-tailed deer in the central Platte River valley and documented late antler casting for this same late-copulating male. An additional male was observed in April of 2020 still retaining antlers within the region. To understand the irregularity of these observations relative to the central Platte River valley, we documented observations of early and late antler casting utilizing long-term cast antler collection and camera trap data. We were able to establish a baseline for antler casting phenology within this region to denote a shift in average casting timeframe (more than one month later than previously recorded in this region) and document early and the latest known antler casting within the literature. Herein, we detail the variation in antler casting phenology for white-tailed deer in this region, and the latest known occurrence of natural breeding in the state. Our findings help us better understand the life history of the Nebraska white-tailed deer population and can assist state wildlife biologists and property managers as they assess seasonal harvest regulations and adaptively manage the changing resource.
\end{abstract}

Keywords: antler casting phenology, copulation, delayed breeding, Nebraska, Odocoileus virginianus, Platte River, white-tailed deer DOI: $10.32873 /$ unl.dc.tnas.41.2

\section{Introduction}

Breeding in white-tailed deer (Odocoileus virginianus) is stimulated by a reduction in photoperiod in autumn (Ditchkoff 2011). In more northerly parts of the United States, most breeding occurs in November and slowly diminishes through December (Diefenbach and Shea 2011), but in southern states, such as Alabama, Mississippi, Louisiana, and Florida, breeding occurs January-March with fawning primarily occurring as late as October (Gray et al. 2002, Diefenbach and Shea 2011, Dye et al. 2012). An extended mating season is common in more temperate regions with nutritional abundance, such as the Midwestern United States. In Nebraska, most mature deer mate during an intense period that commences in midOctober and reaches its peak by mid- to late-November (Menzel and Bouc 1975, NGPC 1991). If not successfully bred, females typically will cycle again after 28-29 days (Cheatum and Morton 1942). Following the normal breeding period, up to half of young females aged six to eight months are fertilized, typically one month later than the adult females (NGPC 1991, Heffelfinger 2006, DeYoung and Miller 2011). If mating is successful, gestation is about 200 days (Ditchkoff 2011), with fawning in Nebraska predominantly occurring in late-May and June (NGPC 1991). Timing of mating is critical to fawn survival, as timing of parturition should coincide with optimal nutrition and plant phenology during the growing season (Turner et al. 2019).

In temperate areas, delays in breeding have been related to skewed sex ratios, hunting pressure, and human disturbance. In areas with high relative female abundance and male-biased harvest, breeding can be delayed by up to a month, thus prolonging the breeding season (Jacobson 1992, DeYoung and Miller 2011). Extended breeding in exploited populations may be due to an insufficient number of males to ensure all females are fertilized during the first estrus cycle (DeYoung and Miller 2011). However, some studies have reported that high female:male ratios do not significantly impact complete 
breeding of females, reproductive success, or herd productivity (Ozoga and Verme 1985; Horejsi et al. 1988; McCulloch and Smith 1991). Increased hunting pressure and human disturbance have been suggested to negatively influence breeding success. However, no differences were observed for pregnancy rates, number of fetuses, or conception date for wild Coues deer (Odocoileus virginianus couesi) that were intentionally and repeatedly disturbed by rifle shots throughout the breeding season compared to those that were undisturbed (Bristow 1992).

The timing of antler casting (shedding), like breeding, coincides with photoperiod, and an increase in day length resulting in a decrease in testosterone levels (Goss 1982, Goss 1983). Additionally, age and health of individuals can contribute to antler casting (Goss 1982, Bubenik et al. 1987, Bubenik 1990a, Bubenik 1990b), with older (Siegler 1968), less healthy individuals typically casting earlier (Jacobson and Griffin 1982). Goss (1983) identified a relationship between latitude and average antler casting timeframe. Southern casting dates are broad and occur from December to April, while at northern latitudes the casting timeframe is more truncated, occurring January-March (Goss 1983). Deer in Illinois initiate antler casting in January and conclude by mid-April (Hawkins et al. 1968), while observations in Minnesota and northern Iowa suggest most antlers are cast in February (Zagata and Moen 1974).

At Nebraska's latitude, casting timeframe for whitetailed deer has been suggested to occur in January and February (Goss 1983), however historical antler casting timeframe accounts in Nebraska are conflicting. Menzel and Bouc (1975) suggested a late-December to early-January antler drop in Nebraska, while NGPC (1991) stated that most males drop their antlers in January and February, and some rarely carry antlers into May. Ongoing white-tailed deer investigations and personal observations within the central Platte River valley suggest that most antler casting occurs later; primarily February and March, but individuals can vary and be as early as December or as late as April (Schoenebeck and Peterson 2014, Peterson et al. 2015, Peterson et al. 2019). To date, records of early, late, and peak antler casting timeframes have yet to be formally described in Nebraska.

The objectives of this communication are to: 1 ) document observations of early and late antler casting, 2) establish a baseline for antler casting phenology, and 3) describe an observation of seasonally late-breeding and breeding behavior within the central Platte River valley, Nebraska.

\section{Study area}

Nebraska lies within the Great Plains region, with a highly variable climate best described as warm temperate with snowy winters, wet, humid summers in the east, and semi-arid summers in the west (Kottek et al. 2006). Our behavioral observations were conducted in the central Platte River valley, Phelps County, Nebraska (Lat: $\left.40^{\circ} 39^{\prime} 27.65^{\prime \prime} \mathrm{N}, 99^{\circ} 10^{\prime} 55.74^{\prime \prime} \mathrm{W}\right)$. This area consists of wetted lowlands and riparian habitat bordered by agricultural fields (Weaver and Bruner 1948). The central Platte River valley is dominated by cropland, woodlands, grasslands, wetlands, open waters, braided shallow river channels with large islands, and mixed shrubby habitat in riparian areas. Row crops adjacent to the river valley consist primarily of corn and soybeans with the remaining agricultural crop consisting of hay fields (primarily alfalfa, in addition to established and native grasses).

Our study area used to determine cast antler phenology for central Nebraska is best described as the riparian and river bottoms of the Platte and South Loup River valleys, and consisted of multiple locations in Buffalo, Dawson, Hall, Kearney, and Phelps Counties (Figure 1).

\section{Methods}

To better understand antler casting phenology (early, late, and peak casting timeframes) within central Nebraska we investigated a variety of available observations and datasets to better quantify antler casting timeframes for this region. We 1) documented harvest dates of cast antlered males, 2) compiled dates that freshly cast antlers were available to be collected in the environment, and 3) investigated regional camera trap captures to determine cast antler phenology. We defined early antler casting as any male white-tailed deer that cast one or both antlers, January $15^{\text {th }}$ or earlier. We defined late antler casting as any male white-tailed deer observed holding one or both antlers, April or later. Peak antler casting was determined by the timeframe fresh casts were available to be collected in the environment in addition to peak drop timeframe developed using camera trap captures.

\section{Males harvested with antlers cast}

Within Nebraska, harvested deer are registered during the rifle season (mid-November) at in-person deer check stations; additionally, during the December and January deer seasons, deer are registered through an online Telecheck system. Communication with Nebraska Game 


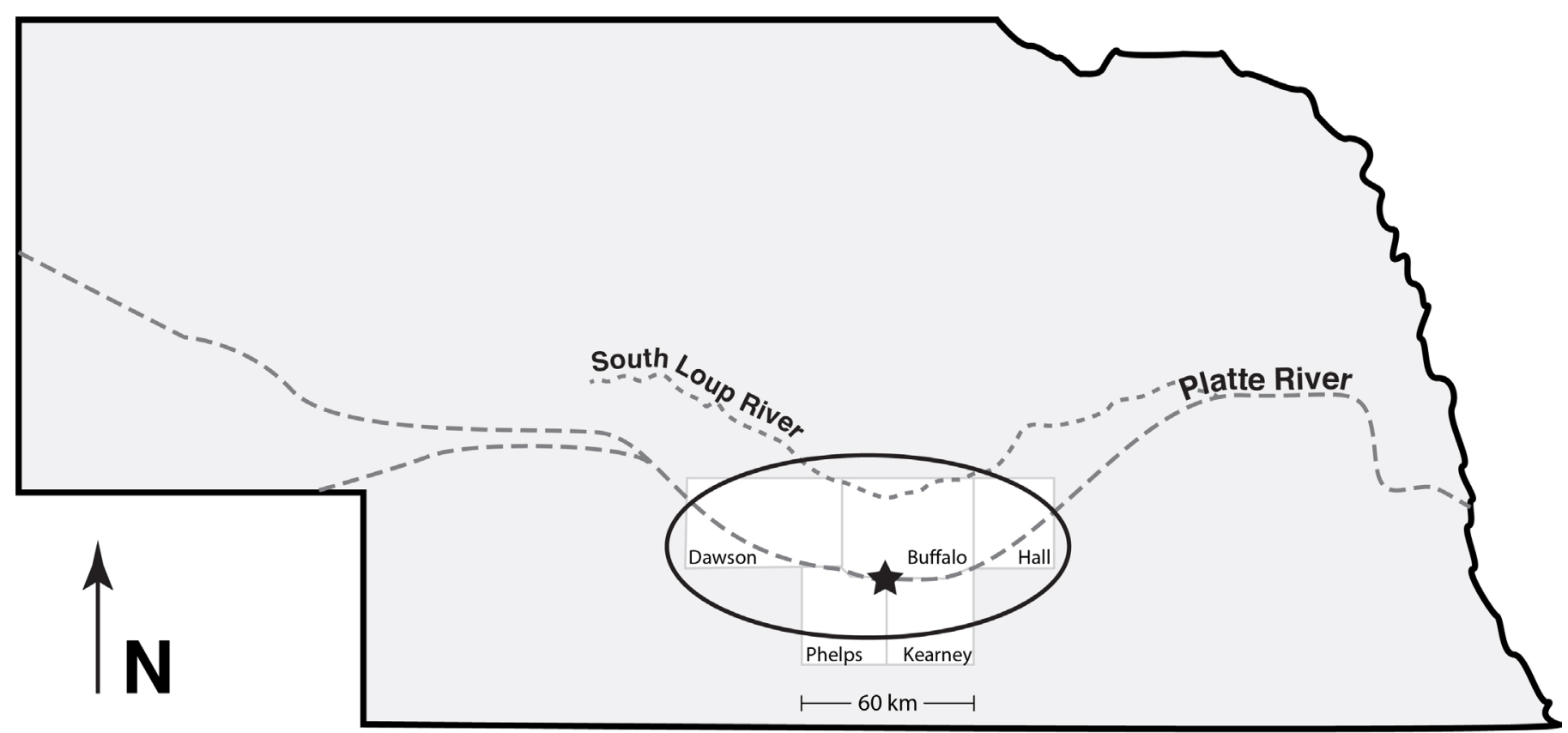

Figure 1. Behavioral observation cast antler collection and camera trapping study area including Counties, Platte River and South Loup River valleys in Nebraska, USA. The oval defines the study area, and the star denotes the late-breeding observation.

and Parks Commission (NGPC) biologists indicated that they do not recall any male deer having cast their antlers during the November firearm season in this region (N. Fryda, NGPC; personal communication). Historically, the NGPC Telecheck system did not capture or differentiate data from harvested adult males that had antlers cast (during the December and January antlerless seasons) until this option was added 12 December 2020 (L. Meduna, NGPC; personal communication). Males which cast their antlers early may be mistakenly harvested as antlerless females during the December muzzleloader/archery or the January river antlerless season. We therefore documented known antlerless males (adults with antlers cast) harvested from word-of-mouth communications (20152021) and available Telecheck data during the 2020 December muzzleloader/archery and 2021 antlerless season which occurs annually the first fifteen days of January.

\section{Cast antler collection dates}

To further define a timeframe for natural antler casting, we determined the mean dates that freshly cast antlers were collected in the environment during an 11-year collection effort (2010-2020). Freshly cast antlers (previous year's antler growth) previously collected proximal to the Platte River valley (Figure 1) were identified as having a waxy skin ring around the perimeter or blood spot present on the base of the antler's pedicle (Schoenebeck and Peterson 2014, Peterson et al. 2019). A collection date provides a conservative casting date as it is positively biased compared to the actual casting date by also including survey opportunities (i.e., how long after antler casting a survey occurred) and cast antler detection (i.e., the probability of finding a cast antler). In addition, we recorded if blood was present on the pedicle base. The visible presence of blood occurs in the pits and spicules of the pedicle of cast antlers, but readily diminishes to clean-white as it is washed off by snow melt, condensation, or a precipitation event, thus providing a more precise casting date range. Therefore, antlers that lack the presence of blood spots may have been cast several more days prior to collection compared to those with blood spots.

We compared blood spot cast antler and non-blood spot cast antler collection dates to understand if nonblood spot cast antlers were collected later than blood spot antlers, thus having additional bias from actual casting date. We also compared collection dates of non-blood spot cast antlers by age. Freshly collected antler casts were categorized into two age groups, 1.5-year-olds or $\geq 2.5$-years-old, based on main beam length (Schoenebeck et al. 2013, Peterson et al. 2019).

We used two-sample t-tests assuming unequal variances to compare bloody vs. non-bloody collection dates 
and collection dates by age. Day of year was determined for all examined fresh casts within each category and utilized in both tests. Both t-test were conducted with onetailed test due to the hypotheses of bloody cast antlers being collected earlier, and younger deer casting antlers sooner than older males (Behrend and McDowell 1967, Zagata and Moen 1974). If a match set was suspected, only the first antler side found was used in the dataset to avoid pseudo-replication. We did not use blood spot antlers in age comparison to reduce the influence of other grouping variables on results. Both tests performed in Program $R$ with package stats ( $R$ Core Team 2020) and used an alpha level of 0.05 to determine statistical significance.

\section{Camera trap investigation}

To better determine seasonal antler casting phenology within central Nebraska, we evaluated white-tailed deer camera captures from multiple camera trapping investigations adjacent to the central Platte River and South Loup River valleys, if active, anytime between 1 November and 29 April (2011-2019). Infrared cameras $(n=31$; primarily Bushnell Trophy Cam, Overland Park, MO, USA, Model 119836C [ $n=26]$ or Moultrie ${ }^{\circledR}$ A-5 Gen 2[n=5]) were deployed and set to take a burst of three photos as described by Reinson (2019) and Peterson et al. (2015). Camera captures of mature males were tallied and determined to be unique if there was at least one blank frame between deer captures within the camera view, following protocols adapted from Reinson (2019). We recorded the number of males retaining both antlers and males with both antlers

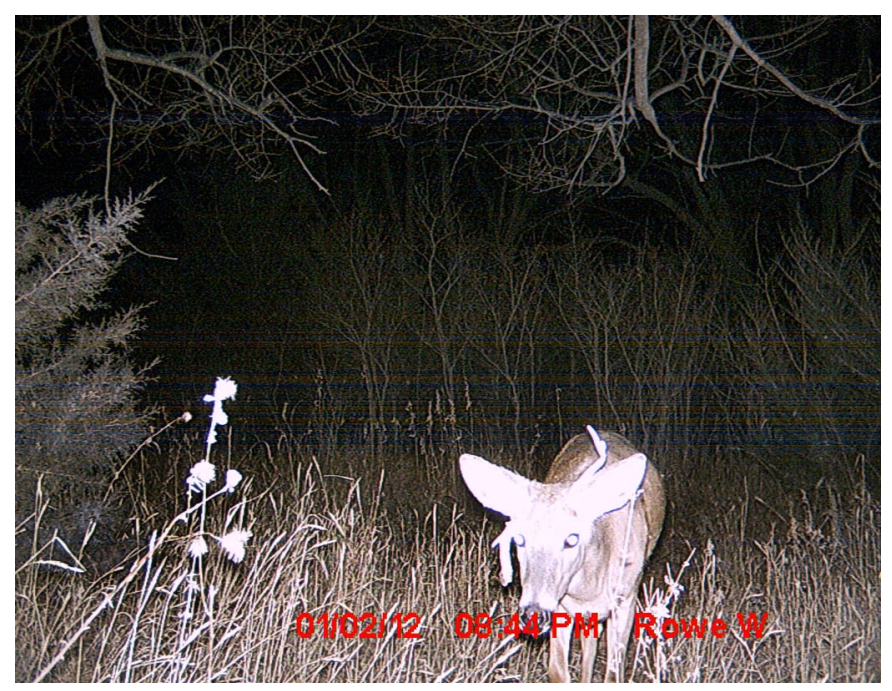

Figure 2. Camera trap capture of early antler casting, 2 Jan 2012, Buffalo County, Nebraska, USA. cast. A documented cast antlered male had to be definitive (i.e., the pedicle or presence of new growth must be visible) as antler breakage is common due to fighting. Evidence of antler breakage at the pedicle base was not recorded as an antler cast. Additionally, we recorded males holding one antler and males with visibly fresh, bloody, or not yet scabbed over pedicles, as this is an indicator of recent casting. We investigated camera captures beginning 1 November and concluding 29 April. We combined low casting timeframe observations between 1 November-14 January and 31 March-29 April, while breaking down 15 January-30 March in 15-day intervals to describe peak casting timeframe.

\section{Results}

\section{Early antler casting}

From our observations, the earliest documented male with antlers cast was observed on 1 January 2019 (Table 1). This individual was found trapped and deceased in a barb wire fence and was not observed trapped the previous day. His antlers may have been cast just prior to 1 January or several days earlier. Camera trap investigations captured a 1.5-year-old male in the process of casting a single antler 2 January 2012 (Figure 2, Table 1). This antler cast was later collected $40 \mathrm{~m}$ from the camera trap site. Harvested early cast antlered males were documented during the January antlerless harvest season $(n=4)$, with the earliest harvest male occurring on 2 January (Table 1). Based on pedicle circumference these males included three 1.5-year-olds and one $\geq 2.5$-year-old. Telecheck data

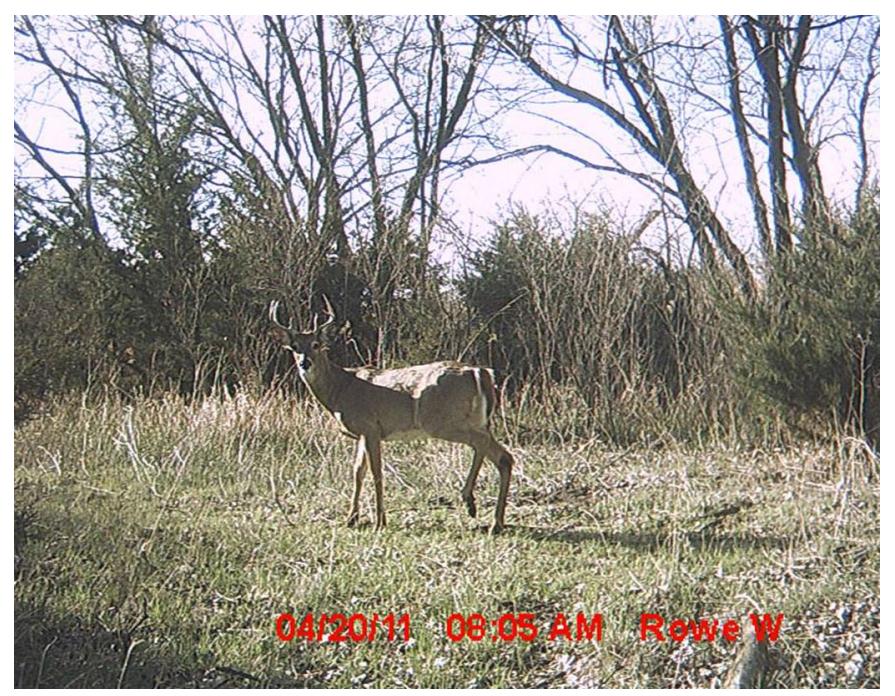

Figure 3. Camera trap capture of late antler casting, $20 \mathrm{Apr}$ 2011, Buffalo County, Nebraska, USA. 


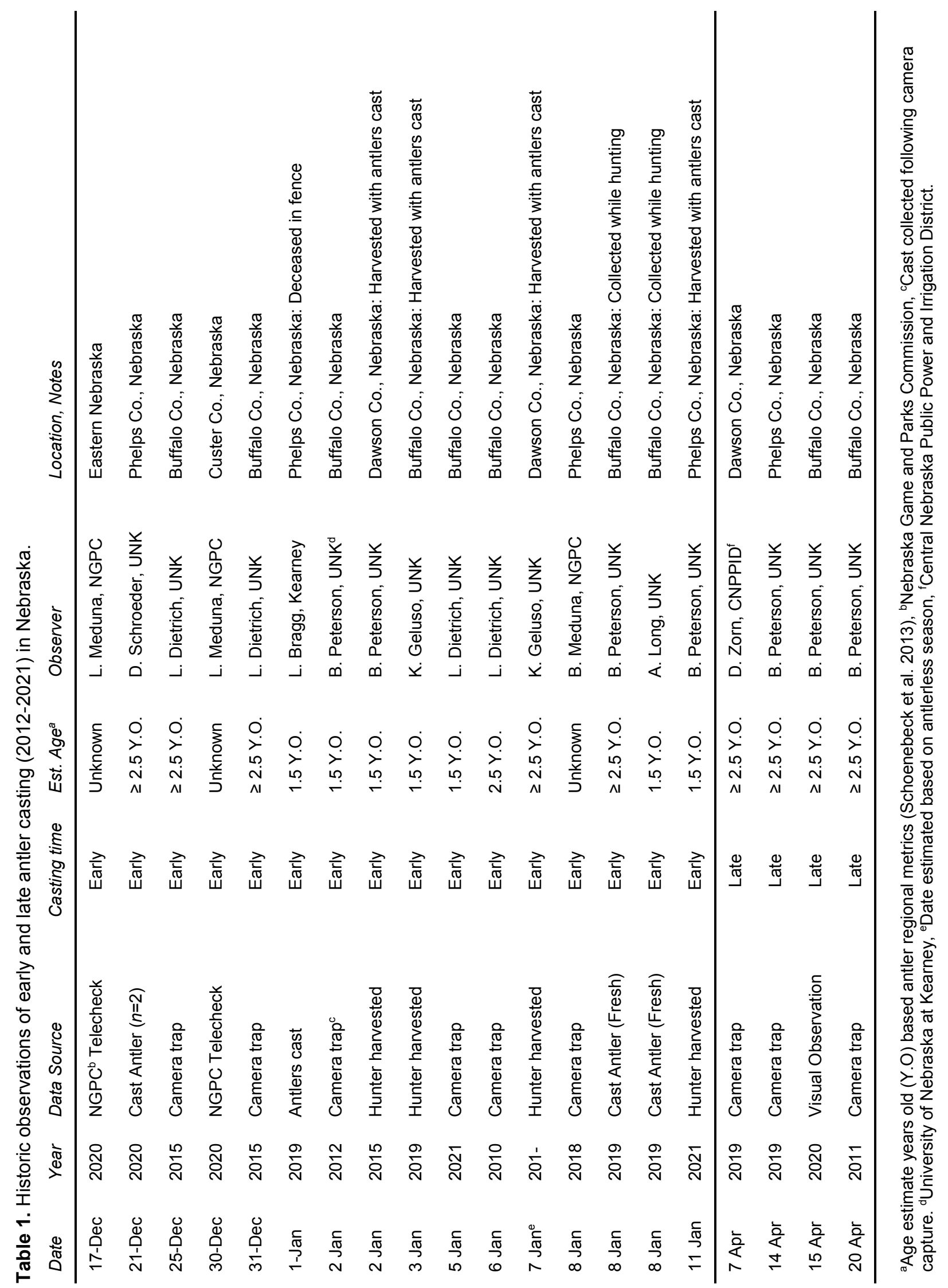


Table 2. Camera trap antler casting observations of male white-tailed deer one-year old or older (1 November - 29 April; 2011-2019) in Nebraska.

\begin{tabular}{|c|c|c|c|c|c|}
\hline & $\begin{array}{c}\text { Males } \\
\text { observed }\end{array}$ & $\begin{array}{l}\text { Both antlers } \\
\quad \text { cast }\end{array}$ & $\begin{array}{c}\text { Percent antlers } \\
\text { cast }\end{array}$ & $\begin{array}{c}\text { One antler } \\
\text { cast }\end{array}$ & $\begin{array}{c}\text { Bloody } \\
\text { pedicles }\end{array}$ \\
\hline Dates & No. & No. & $\%$ & No. & \\
\hline 1 Nov- 14 Jan & 395 & 0 & $0 \%$ & $x^{b}$ & \\
\hline 15 Jan -29 Jan & 51 & 3 & $6 \%$ & 1 & \\
\hline 30 Jan -13 Feb & 61 & 1 & $2 \%$ & 2 & \\
\hline 14 Feb- 28 Feb & 20 & 7 & $35 \%$ & 3 & 1 \\
\hline 1 Mar- 15 Mar & 41 & 33 & $81 \%$ & & 1 \\
\hline 16 Mar- 30 Mar & 67 & 55 & $82 \%$ & & 7 \\
\hline $31 \mathrm{Mar}-29 \mathrm{Apr}$ & 111 & $110^{c}$ & $99 \%$ & & \\
\hline
\end{tabular}

${ }^{a}$ Included in cast antler tally, ${ }^{b}$ captured in the process of casting a single antler but process not completed ( 2 Jan), ${ }^{c}$ retaining both antlers (20 April).

recorded at total of 99 cast antler white-tailed deer males harvested within the state between (12 December 2020 and 15 January 2021), with 10 males harvested in December and 89 males harvested in the first fifteen days of January. The earliest harvested male with antlers cast was recorded via Telecheck 17 December 2020 in Eastern Nebraska. Within our study area 11 total cast antler males were harvested with 1 male harvested in December (Custer County) and 10 males harvested in January (Buffalo $(n=2)$ Dawson $(n=3)$, Hamilton $(n=1)$, Kearney $(n=1)$ and Phelps $(n=3)$ Counties. The earliest recorded Telecheck harvested individual in our study area with cast antlers was recorded 30 December 2020 (Table 1). We documented four early freshly cast antlers between 2010 and 2020 with the earliest collected 21 December 2020 (Table 1) within the central Platte River valley.

\section{Late antler casting}

The latest recorded observation of a male still retaining antlers occurred on 20 April 2011 (Figure 3, Table 1). Late antler casting observations during April consisted of all older males estimated to be $\geq 2.5$-years-old ( $n=4$; Table 1 ).

\section{Peak antler casting}

We examined 346 freshly cast antlers which were available in the environment to be collected. We found that $22.3 \%(n=77)$ contained the presence of blood on the pedicle seal while $77.7 \%(n=269)$ were clean. The average collection date for fresh casts containing blood was earlier than fresh casts without. On average, fresh casts with blood were collected on 9 March $\pm 1.8 \mathrm{SE}(n=77)$ while fresh casts without blood were collected on 13 March \pm 1.0 SE $(n=269)$ and the results were statistically significant $(t(126.83)=-1.89, P=0.03)$.

The average collection date was similar for both age classes. The mean collection date for 1.5-year-olds averaged 11 March \pm 1.5 SE $(n=102)$ while $\geq 2.5$-year-olds averaged a collection date of 9 March $\pm 1.7 \mathrm{SE}(n=118)$ but results were not statistically significant $(t(215.6)=0.94, P=0.17)$.

\section{Camera trap investigation}

During the camera trap investigation effort (1 November to 29 April, 2011-2019) a total of 746 males were classified, of which $72.0 \%(n=537)$ retained both antlers, $28.0 \%$ $(n=209)$ had cast both antlers, and $0.1 \%(n=6)$ had one antler cast. We observed that no complete antler casting occurred between 1 November and 16 January, however a young male was camera captured in the process casting his right antler 2 January 2012 (Figure 2; Table 2). The first complete casting (both antlers) was observed on 17 January. The first male classified in the process of complete antler casting while only retaining one antler was observed on 27 January $(n=1)$, with additional observations occurring between 3 and 25 February $(n=5)$. Males with fresh, bloody pedicles were observed between 20 February and 18 March $(n=9)$. The latest observed male still carrying one or more antlers occurred on the 20 April 2011 (Figure 3; Peterson et al. 2015). Based on our camera 
Brian C. Peterson, Patrick D. Farrell, Dave Fehlhafer, Miranda C. Reinson, and Dustin H. Ranglack

Table 3. Behavioral observations and late antler casting of a late-breeding male white-tailed deer during the spring of 2019 in Nebraska.

\begin{tabular}{|c|c|c|c|c|}
\hline Date & Location & Behavioral and Physical Observations & Observation Type & Figure \\
\hline $25 \mathrm{Feb}$ & Woods adj. alfalfa & Sequence of scenting and chasing behavior & Camera trap (L. Bragg) & Figure $5 a$ \\
\hline $5 \mathrm{Apr}$ & Alfalfa field & Antlered male trailing young female & Visual/Binoculars & - \\
\hline $5 \mathrm{Apr}$ & Grass/accretion area & Breeding a single young female & Visual/Binoculars & - \\
\hline $5 \mathrm{Apr}$ & Woods adj. alfalfa & Trailed young female into woods, out of sight & Visual/Binoculars & - \\
\hline $6 \mathrm{Apr}$ & Alfalfa field & Enlarged testes, scrotum evident when chasing & Camera/Video & Figures $4 a, 4 b$ \\
\hline $10 \mathrm{Apr}$ & Woods adj. Platte River & Scent checking, enlarged testes, retaining both antlers & Camera trap (L. Bragg) & Figure $5 b$ \\
\hline $13 \mathrm{Apr}$ & Alfalfa field & Following several females, retaining both antlers & Camera trap & Figure $5 \mathrm{c}$ \\
\hline $14 \mathrm{Apr}$ & Grass/accretion area & Browsing, following four females, retaining both antlers & Camera trap & Figure $5 d$ \\
\hline
\end{tabular}

capture effort, the peak casting timeframe occurred the last fifteen days of February through the first fifteen days of March, with all males (apart from the late casting 20 April male) observed having antlers cast by the end of March (Table 2).

\section{Late-Breeding and Antler Casting Observations}

An opportunistic behavioral observation of white-tailed deer was made by B. Peterson and D. Fehlhafer at a subirrigated alfalfa field, located immediately south of the Platte River in the northeastern most section of Phelps County, Nebraska (Figure 1). At 0730 on 5 April 2019, an average-body sized young female was observed being trailed by a large-bodied mature male (hereinafter latebreeding male) with unique, tall, thick, non-symmetric antlers containing at least three measurable points on each side as defined by Nesbitt et al. (2009). Typically, an observation such as this would not be unusual; however, it was seasonally late for a male to retain antlers in this region (Table 3; Goss 1983). We observed this late-breeding male closely trailing the female through the field until they reached the uncultivated accretion ground or historic south bank of the Platte River (Table 3). The male and female remained in this grassy depression for approximately twenty minutes, during which the male was observed (with binoculars; Nikon Monarch 3, 10 x 42; from approximately 270 meters away) mounting and copulating with the young female twice (Table 3 ). The young female bedded once, and each time she moved, the latebreeding male closely followed. Observations continued until the pair moved into the woods and out of sight at approximately 0750 . The following morning (6 April 2019) the same late-breeding male (identified by body size and unique antler morphology) was observed 0711-0716 in the same sub-irrigated alfalfa field, 200 meters west of previous day's location (Table 3). This deer's behavior was captured via photos and video (Sony RX10 IV 24 x $600 \mathrm{~mm}$ ) from approximately 250 meters away. During this observation, the late-breeding male was associated with one mature and three young females (based on body size and morphology) and exhibited repeated common breeding behaviors including (downwind) scent-checking, nose licking, and minor but evident female chasing (Table 3, Figure 4a \& 4b). No additional copulations were seen during this day's observation. These observations, to our knowledge, represent the latest documented breeding and breeding behavior by white-tailed deer in Nebraska.

This late-breeding male was later identified as being in the area since at least 25 February 2019, when he was captured in a sequence of trail camera photos, scent checking and chasing two young females (Figure 5a). Using photographs, video footage and trail camera pictures, we estimated that this late-breeding male was approximately 3.5 to 4.5 -years-old based on antler size, muscle tone, and body size consistent for males within this region. Additionally, it was noted from photographs, video, and numerous trail camera photos (Feb-Apr), that the late-breeding male's scrotum/testes appeared protracted and abnormally enlarged (Figure $4 \mathrm{a} \& 4 \mathrm{~b}$ and $5 \mathrm{~b}$ ) and remained a readily identifiable characteristic through April (several days following antler casting). 

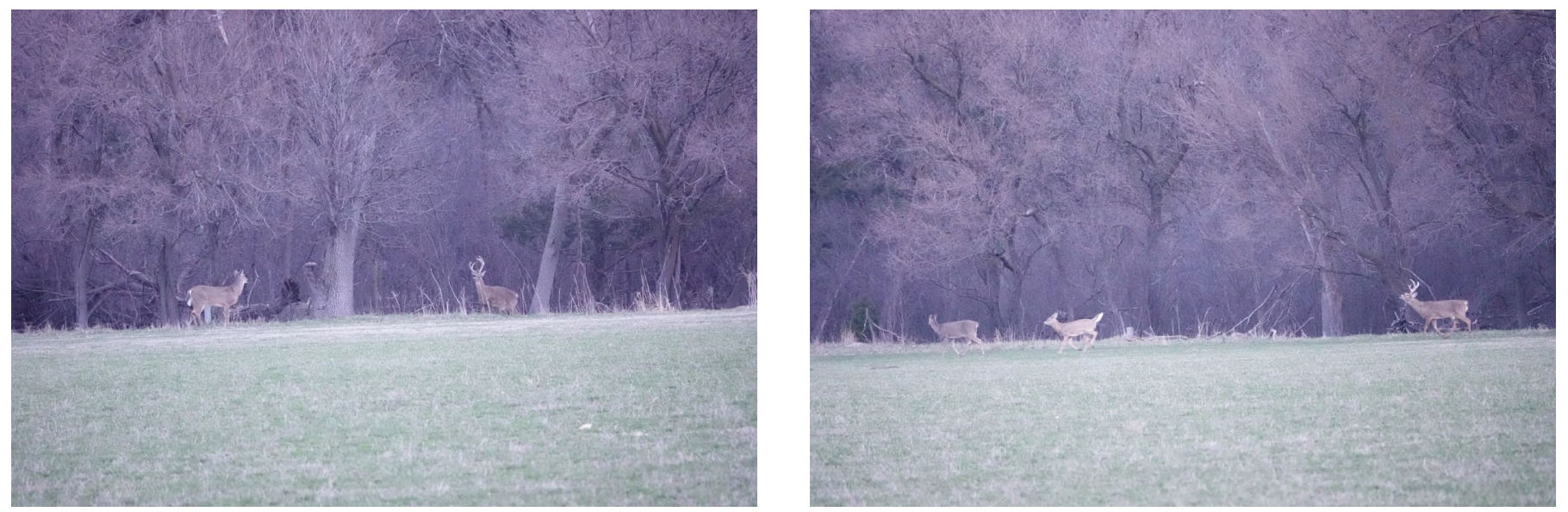

Figure 4a, 4b. Late-breeding males minor chasing and scent checking behavior, 6 Apr 2019, Phelps County, Nebraska, USA.
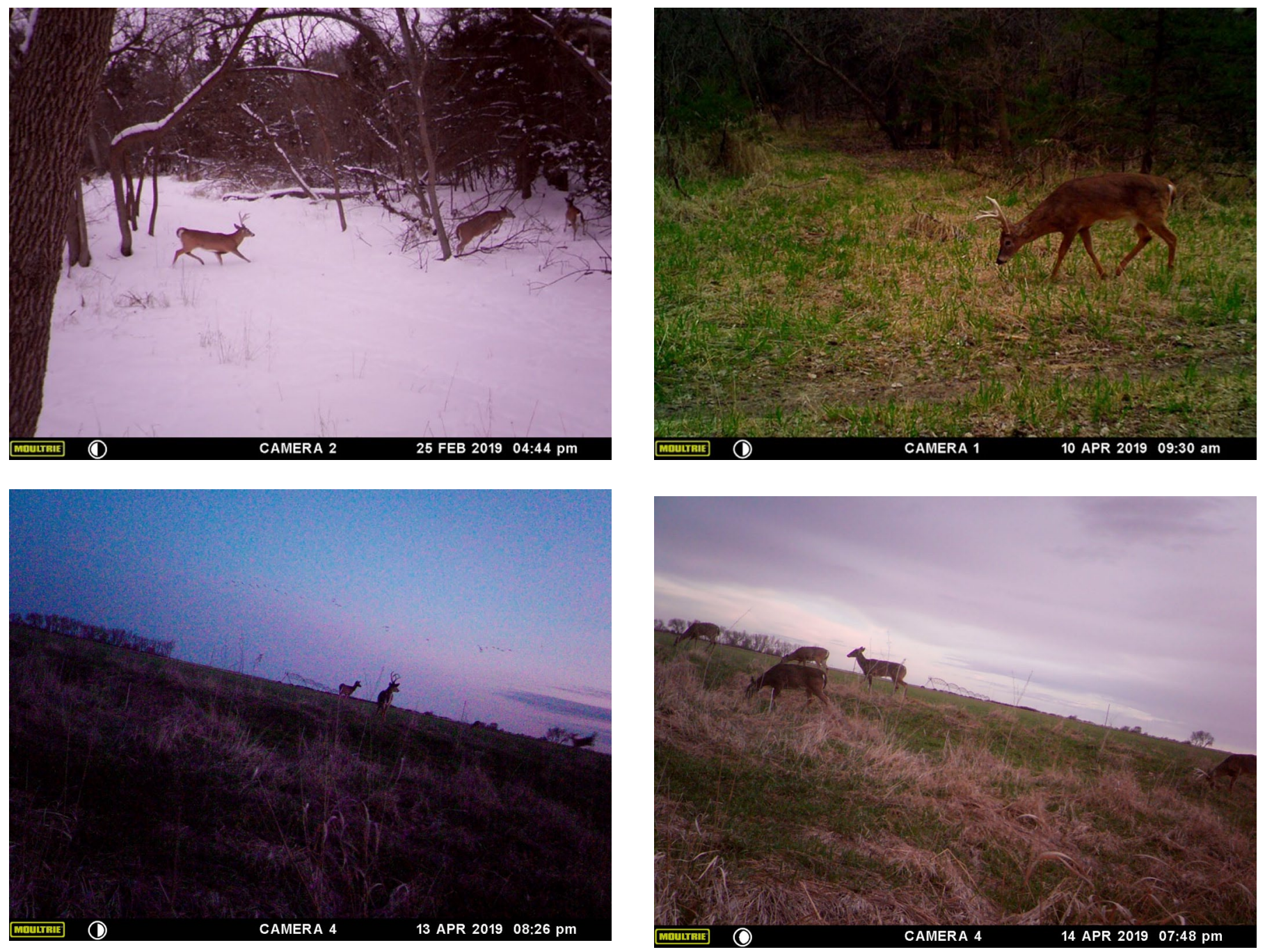

Figure 5a-d. Camera captures of late-breeding male carrying both antlers February through April of 2019. 

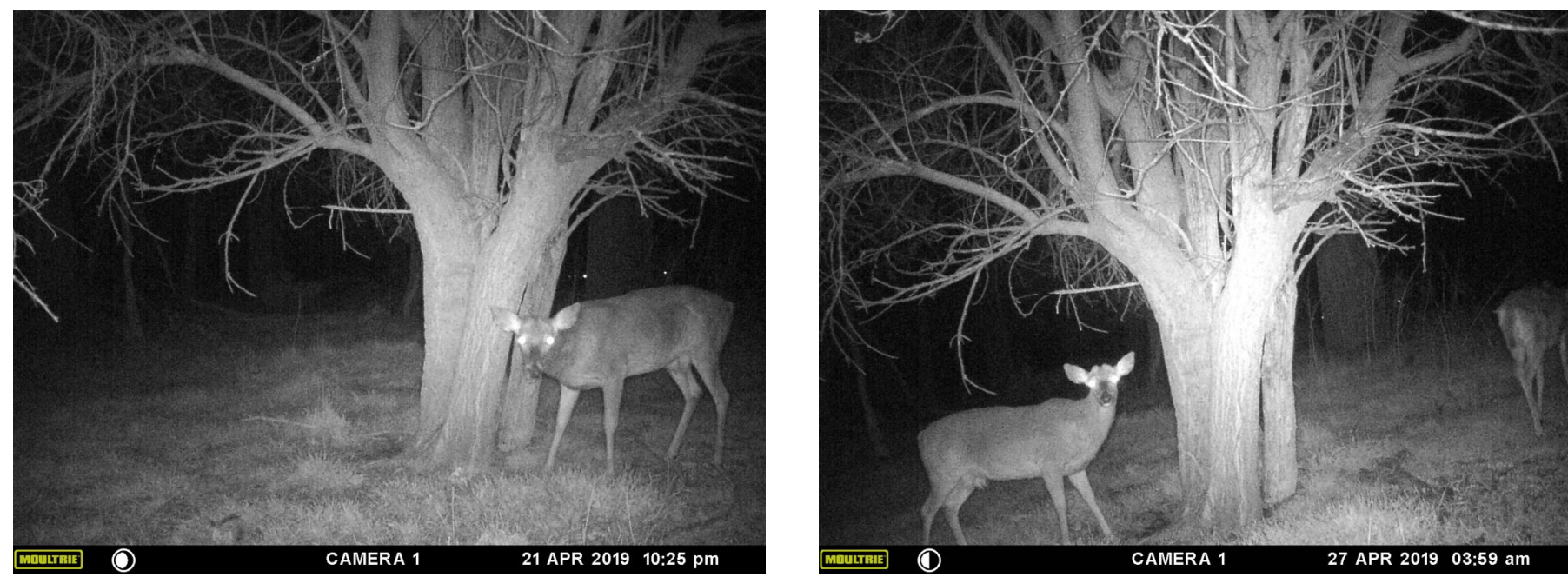

Figure 6a, 6b. Late-breeding male following antler casting, clearly identified as testicles are still enlarged, 21-27 Apr 2019, Phelps County, Nebraska, USA.

Following behavioral observations, three infraredtriggered trail cameras were placed in the observation area to determine casting date of the late-breeding male. Camera traps captured the late-breeding male on three occasions still retaining antlers and following females; however, specific behaviors could not be determined (Table 3). The late-breeding male was observed several times after 21 April 2019, with antlers cast (unmistakably identified by his enlarged testes; Figure $6 a \& 6 b$ ), however the male's pedicles were scabbed, and pictures dark therefore precise casting date could not be determined. It is presumed antlers were cast 14-20 April 2019 based on camera captures. Beyond 27 April 2019, the final observation, this male either left the immediate area or was no longer identifiable.

In addition to the late-breeding and casting observation described in 2019, on 15 April 2020, another male (approximately 2.5-years-old based body size and antler morphology) was observed still retaining both antlers and closely trailing a group of six young females (Table 3). This observation occurred in a cut cornfield, adjacent to a drainage of the Platte River, Buffalo County., Nebraska, four kilometers northeast of the 2019 late-breeding male observation.

\section{Discussion}

We observed that white-tailed deer within the central Platte River valley, on average, had a broader and later casting timeframe than previously documented for this region. Early and late casting was documented to occur in early-January and late-April, respectively. Early antler casting is typically observed by older individuals (Siegler 1968) or those less healthy (Jacobson and Griffin 1982) within a population. Deer that cast their antlers early (December-January), typically have flat to negative seal depths suggesting lower peak testosterone levels and less healthy individuals (Bubenik et al. 1987, Bubenik 1990a, Bubenik 1990b, Peterson et al. 2019) which is consistent with personal observations of early cast antler males recovering from epizootic hemorrhagic disease (EHD; based on sloughed or peeling hoofs) or in poor body condition (decreased weight and visible bodily injuries). The earliest cast antler collected was from a 1.5-year-old male which was observed casting his antler on 2 January (Figure 2). After collection of that individual's cast antler and further investigation, we observed that the pedicle of the cast antler was concave indicating this individual was stressed or in poor health (Peterson et al. 2019) which is consistent with Jacobson and Griffin (1982) who suggested that in white-tailed deer antler size has no relationship to antler casting timeframe, but unhealthy males under poor nutritional conditions may cast earlier than those which are healthier.

Antler cycle is closely related to androgen concentrations (Bubenik 1990b) and several studies on cervids have observed that artificially elevated testosterone delays normal antler casting (Lincoln et al. 1972, Semepere and Bois$\sin 1982)$. Late antler casting is not uncommon amongst individuals in good condition within cervid populations, for example male pampas deer (Ozotoceros bezoarticus) in the presence of females cast their antlers later compared 
to male-only groups (Ungerfeld et al. 2009) which indicates increased testosterone levels. Female white-tailed deer that remain in estrus or come into estrus late may cause extended periods of elevated testosterone levels in males and result in late antler casting which may explain the late-breeding male retaining antlers until at least 14 April 2019 and the antlered male documented on 15 April 2020 represent additional observations of late antler casting for this region.

It is difficult to determine the factors causing a shift to a broader and later average casting timeframe than previously documented in Nebraska. It could be due to climatic factors which have been shown to advance estrous date, parturition date and antler casting in cervids (Moyes et al. 2011) or may be due to the lack of historical documentation of antler casting observations to accurately determine average casting timeframe. Further investigations should build upon and validate our findings, in addition to evaluating and comparing average casting dates between regions, populations and years.

It has been suggested that younger males (yearlings) typically retain their antlers longer than older larger antlered males (Behrend and McDowell 1967). During 11 years of central Platte River valley cast antler collecting (Schoenebeck and Peterson 2014, Peterson et al. 2019) and camera capture (Peterson et al. 2015, Reinson 2019) investigations within this region; we observed that larger (older) males typically cast slightly earlier than younger males. Such observations could be due to a less dramatic decrease in testosterone levels that occur in younger males (Siegler 1968, Heffelfinger 2006). Our results supported this trend, as cast antlers of older deer were collected two days earlier on average in the central Platte River valley; however, the late casting males we observed were both older deer based on body and antler size, which is consistent with Zagata and Moen (1974), in which larger antlers were retained longer than smaller antlers. Further observations and investigations with a more targeted study and data collection design is warranted.

White-tailed deer are seldom observed mating in the wild, and when observed, exact dates are rarely documented (Haugen and Davenport 1950). Male reproductive studies are lacking in the literature due to the lack of efficient methods to measure reproductive male effort (Mysterud et al. 2004). Our observation of late season breeding from a single male white-tailed deer represents the latest recorded of such reproductive behaviors in the central Platte River valley and state of Nebraska. Without knowing the underlying circumstances of the young breeding female, we can only speculate as to her reproductive status. We cannot confirm the young female we observed was present both days; however, it is possible as unbred females can be receptive for up to 48 hours (Knox et al. 1988). Given the visual cues (small bodied and short snout), the breeding female may have been a late fawn reaching reproductive maturity, since whitetails are capable of breeding later in the Midwest (Zagata and Moen 1974), with $75 \%$ of Iowa fawns breeding in late winter (Haugen 1975), and 60\% of fawns breeding following the mature female reproductive period in Nebraska (NGPC 1991). Another plausible explanation could be that the young female was not successfully bred, and additional attempts may be attributed to reoccurring estrous cycles (Verme 1961). Under penned conditions, Knox et al. (1988) reported up to seven estrous cycles by a female white-tailed deer during a single breeding season. If testosterone levels have dropped in the herd, it may be advantageous for our late-breeding male to seek young females late, as actively breeding males have been shown to induce breeding of pen raised female white-tailed deer (Verme et al. 1987), thus increasing the opportunity for reproductive success.

If breeding were successful during our late-breeding observation, a fawn conceived from this breeding would be born in October (based on a 200-day gestation period; Ditchkoff 2011). A late birth would put a fawn at risk of survival as they likely will not reach critical body mass during their first winter due to the lack of fat reserves compared to individuals within the same cohort (Zagata and Moen 1974). While success of late fawning, survival, and recruitment to the population would be unlikely in the Midwest, later fawn births are successful at more southern latitudes, but late-breeding and fawning are not always positive (Zagata and Moen 1974) as it can negatively affect body size, antler mass, and reproductive potential (Diefenbach and Shea 2011).

Within the central Platte River valley, sex ratios may to be skewed in favor of females, however ratios have yet to be formally determined for this area. Skewed sex ratios in white-tailed deer towards females can cause incomplete breeding within a population during the first breeding cycle (DeYoung and Miller 2011). Future investigations should monitor sex ratio fluctuations and effects that those exploited populations may contribute to incomplete breeding.

We documented that the late-breeding male's testes were abnormally large compared to other males of similar age and body size during this timeframe in this area. 
A significant positive correlation has been found between testicular volume and testosterone concentrations of captive fallow deer (Dama dama), and mature males showed higher testosterone levels than younger males outside the reproductive season (Pizzutto et al. 2019). During the height of breeding season, it is not unusual for a male's testicles to enlarge, however this condition subsides postbreeding season as testosterone levels drop (Mirarchi et al. 1977). The testes typically reach pre-reproductive mass three months following breeding season (Ditchkoff 2011) with lowest weights occurring between February and June (Mirarchi et al. 1977), suggesting our observations were seasonably late. Our observed testes size may also be an indicator of a more serious issue such as chemical imbalance, hernia, or injury to the testes (Hoy et al. 2002) or disease like EHD, which has been shown to disrupt the proper circulation and production of hormones within the testes (Heffelfinger 2006). Whatever the cause, the abnormally large testes may have influenced male's behavior and delayed antler casting.

It may be reasonable to deduce that if the female were in estrous this could maintain or elevate testosterone levels within the late-breeding male, resulting in late casting. These observations represent the latest documented breeding of free-ranging white-tailed deer in Nebraska; however, until other similar observations are made with males retaining antlers and breeding late, this is best denoted to as an abnormal observation.

Our antler casting phenology findings and breeding observations serve as a baseline for future spatial and temporal comparisons. We can only speculate on causality of the single late-breeding observations, shift in average casting timeframe, and late casting of antlers. As outdoor enthusiasts, wildlife professionals and property managers observe herds containing late antlered males within their region, it is important that they remain diligent in recording and documenting potential late-breeding behaviors at the individual and population level. Better understanding the life history of the population will assist in guiding state wildlife biologists and property managers as they assess seasonal harvest regulations and adaptively manage the changing resource.

Acknowledgements - We thank Keith Geluso, Greg Wright, and Dave Zorn for reviewing early drafts and improving the overall quality of this manuscript and Editor Bruce Chase and anonymous reviewers for enhancing the manuscript through the review process. We thank Larry Bragg for providing supplemental trail camera pictures to better define age, behavior, and evaluate the breeding male's unusual reproductive organs. We thank Luke Meduna from the Nebraska Game and Parks Commission for supplying supplemental data from Telecheck of harvested males with antlers cast. We thank Anna-Maria Easley and Rick Simonson for creating the study area figure. We thank the multiple private landowners and organizations that permitted land access for cast collecting over this 11-year investigation including Audubon's Rowe Sanctuary, Central Nebraska Public Power and Irrigation District, City of Kearney, The Crane Trust, Meyers Homestead Preserve, Nebraska Public Power District, Platte River Recovery Implementation Program and The Nature Conservancy. The Institutional Animal Care and Use Committee at the University of Nebraska at Kearney reviewed and approved all animal capture, handling, marking techniques (IACUC \#091217) and field study exemptions (IACUC \#090821).

\section{Literature cited}

Behrend DF, and McDowell RD. (1967) Antler shedding among white-tailed deer in Connecticut. The Journal of Wildlife Management 31: 588-590.

Bristow KL. (1992) Effects of simulated hunting during the rut on reproduction and movement of Coues white-tailed deer. M.S. Thesis University of Arizona, Tucson. 39pp.

Bubenik AB. (1990a) Epigenetical, morphological, physiological, and behavioral aspects of evolution of horns, pronghorns, and antlers. Pages 3-113 in GA Bubenik and AB Bubenik (Editors), Horns, Pronghorns, and Antlers Springer-Verlag, New York, New York, USA.

Bubenik GA. (1990b) The antler as a model in biomedical research. Pages 474-487 in GA Bubenik and AB Bubenik (Editors), Horns, Pronghorns, and Antlers Springer-Verlag, New York, New York, USA.

Bubenik GA, Schams D, and Coenen G. (1987) The effect of artificial photoperiodicity and antiandrogen treatment on the antler growth and plasma levels of LH, FSH, testosterone, prolactin and alkaline phosphatase in the male white-tailed deer. Comparative Biochemistry and Physiology. A Comparative Physiology 87: 551-559.

Cheatum ET, and Morton GH. (1942) Techniques used in determining the period of rut among white-tailed deer in New York State. Transactions of the North American Wildlife Conference 7: 334-342.

DeYoung RW, and Miller KV. (2011) White-tailed deer behavior. in DG Hewitt (Editor) Biology and Management of White-tailed Deer pp. 324-367. Boca Raton, FL: CRC Press.

Diefenbach DR, and Shea SM. (2011) Managing white-tailed deer: eastern North America. in DG Hewitt (Editor) Biology 
and Management of White-tailed Deer pp. 481-500. Boca Raton, FL: CRC Press.

Ditchkoff SS. (2011) Anatomy and Physiology. in DG Hewitt (Editor) Biology and Management of White-tailed Deer pp. 4373. Boca Raton, FL: CRC Press.

Dye MP, Demarais S, Strickland BK, Jones PD, McDonald CG, and Prochaska DF. (2012) Factors affecting conception date variation in white-tailed deer. Wildlife Society Bulletin 36: 107-114.

Gray WN, Ditchkoff SS, Causey MK, and Cook CW. (2002) The yearling disadvantage in Alabama deer: effect of birth date on development. In Proceedings of the Annual Conference of the Southeastern Association of Fish and Wildlife Agencies 56: 255-264.

Goss RJ. (1982) Control of deer antler cycles by photoperiod. In R.D. Brown, ed. Antler Development in Cervidae. Caesar Kleberg Wildlife Research Institute, Kingsville, TX.

Goss RJ. (1983) Deer Antlers: Regeneration, Function and Evolution. New York, NY: Academic Press.

Haugen AO. (1975) Reproductive performance of white-tailed deer in Iowa. Journal of Mammalogy 56(1): 151-159.

Haugen AO, and Davenport LA. (1950) Breeding records of whitetail deer in the Upper Peninsula of Michigan. The Journal of Wildlife Management 14: 290-295.

Hawkins RE Schwegman, JE, Autry DC, and Klimstra WD. (1968) Antler development and loss for southern Illinois white-tailed deer Journal of Mammalogy, 49: 522-523.

Heffelfinger J. (2006) Deer of the Southwest: A Complete Guide to the Natural History, Biology, and Management of Southwestern Mule Deer and White-tailed Deer. pp. 77-96. Texas A\&M University Press.

Horejsi RG, Haywood DD, and Smith RH. (1988) The effects of hunting on a desert mule deer population. Federal Aid Project W-78-R, WP2, Job 27. Arizona Game and Fish Department, Phoenix. 25 pp.

Hoy JA, Hoy R, Seba D, and Kerstetter TH. (2002) Genital abnormalities in white-tailed deer (Odocoileus virginianus) in west-central Montana: pesticide exposure as a possible cause. Journal of Environmental Biology 23: 189-197.

Jacobson HA. (1992) Deer condition response to changing harvest strategy, Davis Island, Mississippi. In The Biology of Deer (pp. 48-55). Springer, New York, NY.

Jacobson HA, and Griffin RN. (1982) Antler cycles of whitetailed deer in Mississippi. In Antler Development in Cervidae. Caesar Kleberg Wildlife Research Institute, Kingsville, TX, pp.15-22.

Knox WM, Miller KV, and Marchinton RL. (1988) Recurrent estrous cycles in white-tailed deer. Journal of Mammalogy 69: 384-386.

Kottek M, Grieser J, Beck C, Rudolf B, and Rubel F. (2006) World map of the Köppen-Geiger climate classification updated. Meteorologische Zeitschrift 15: 259-263.
Lincoln GA, Guinness F, and Short RV. (1972) The way in which testosterone controls the social and sexual behavior of the red deer stag (Cervus elaphus). Hormones and Behavior 3: 375-396.

McCulloch CY, and Smith RH. (1991) Relationship of weather and other variables to the condition of the Kaibab deer herd. Technical Report No. 11. Arizona Game and Fish Department, Phoenix. 98 pp.

Menzel K, and Bouc K. (1975) The deer of Nebraska. Nebraska Game and Parks Commission Publications 123.

Mirarchi RE, Scanlon PF, and Kirkpatrick RL. (1977) Annual changes in spermatozoan production and associated organs of white-tailed deer. The Journal of Wildlife Management 92-99.

Moyes K, Daniel H, Nussey MN, Clements MN, Guinness FE, Morris A, Morris S, Pemberton JM, Loeske EBK, and Clutton-Brock TH. (2011) Advancing breeding phenology in response to environmental change in a wild red deer population. Global Change Biology 17: 2455-2469.

Mysterud A, Langvatn R, and Stenseth NC. (2004) Patterns of reproductive effort in male ungulates. Journal of Zoology 264: 209-215.

Nebraska Game and Parks Commission Publications. (1991) White-tailed deer (Odocoileus virginianus). 14. URL: https://digitalcommons.unl.edu/nebgamepubs/14

Nesbitt WH, Wright PL, Buckner EL, Byers CR, and Reneau J. (2009) Measuring and scoring North American big game trophies. Boone and Crockett Club pp. 176 Missoula, Montana, USA.

Ozoga JJ, and Verme LJ. (1985) Comparative breeding behavior and performance of yearling vs. prime-age white-tailed bucks. Journal of Wildlife Management 49: 364-372.

Peterson BC, Koupal KD, Schissel A, and Siegel CM. (2015) Longevity of mineral supplements within the soil and associated use by white-tailed deer. Transactions of the Nebraska Academy of Sciences 35: 61-67.

Peterson BC, Schoenebeck CW, and Fryda NJ. (2019) Effects of extreme environmental conditions on white-tailed deer antlers. Wildlife Society Bulletin 43: 708-716.

Pizzutto CS, Corrêa SH, Teixeira RH, Rosenfield DA, Jorge Neto PN, Berbare P, Rodriguez, EG, and Oliveira CA. (2019) Seasonal variations in serum concentrations of testosterone, testicular volume and neck circumference of fallow deer (Dama dama) kept ex situ in a tropical region. Zoo Biology 38: 355-359.

R Core Team. (2020) R: A language and environment for statistical computing. R Foundation for Statistical Computing, Vienna, Austria. URL https://www.R-project. org/.

Reinson MC. (2019) Influences of habitat fragmentation and agriculture on white-tailed deer (Odocoileus virginianus) 
ecology. Thesis. The University of Nebraska at Kearney, Kearney, USA. 79 pp.

Schoenebeck CW, and Peterson BC. (2014) Evaluation of hunter antler-size selection through an age-specific comparison of harvested and naturally cast antler metrics. Journal of Fish and Wildlife Management 5: 167-173.

Schoenebeck CW, Peterson BC, and Obermiller JA. (2013) Accuracy of antler metrics in predicting age of white-tailed deer and mule deer. Great Plains Research 23: 33-37.

Semepere AJ, and Boissin J. (1982) Neuroendocrine and endocrine control of the antler cycle in roe deer. In Antler Development in Cervidae. Caesar Kleberg Wildlife Research Institute, Kingsville, TX, pp.109-122.

Siegler HR. (1968) Life history of deer in New Hampshire. The white-tailed deer of New Hampshire (HR Siegler, ed.). New Hampshire Fish and Game Dept., Concord, 29-55.

Turner MA, Gulsby WD, Ditchkoff SS, Gray WN, and Cook CW. (2019) Effects of breeding chronology on white-tailed deer productivity in Alabama. Wildlife Society Bulletin 43: 701-707.

Ungerfeld R, Damián JP, Villagrán M, and GonzálezPensado SX. (2009) Female effect on antlers of pampas deer (Ozotoceros bezoarticus). Canadian Journal of Zoology 87: 734-739.

Verme LJ. (1961) Late breeding in northern Michigan deer. Journal of Mammalogy 42(3): 426-427.

Verme LJ, Ozoga JJ, and Nellist JT. (1987) Induced early estrus in penned white-tailed deer does. The Journal of Wildlife Management 54-56.

Weaver JE, and Bruner WE. (1948) Prairies and pastures of the dissected Loess Plains of Central Nebraska. Ecological Monographs 18: 507-549.

Zagata MD, and Moen AN. (1974) Antler shedding by whitetailed deer in the midwest. Journal of Mammalogy 55(3): 656-659. 